\title{
Factors influencing bug diversity (Insecta: Heteroptera) in semi-natural habitats
}

\author{
CORINNE ZURBRÜGG ${ }^{1}$ and THOMAS FRANK ${ }^{1,2, *}$ \\ ${ }^{1}$ Zoological Institute, University of Bern, Baltzerstrasse 6, CH-3012 Bern, Switzerland; ${ }^{2}$ Present \\ address: Institute of Zoology, Department of Integrative Biology, University of Natural Resources \\ and Applied Life Sciences, Gregor Mendelstrasse 33, A-1180 Vienna, Austria; *Author for corre- \\ spondence (e-mail: thomas.frank@boku.ac.at; phone: +43-1-47654-3201; fax: +43-1-47654-3203)
}

Received 9 July 2004; accepted in revised form 7 December 2004

Key words: Agroecosystems, Bug community, Canonical correspondence analysis, Ecological compensation areas, Flower abundance, Functional groups, Insect diversity, Species richness, Vegetation structure

\begin{abstract}
We investigated the abundance and species richness of heteropteran bugs and explored environmental factors which influence bug diversity in three types of semi-natural habitats (wildflower areas, extensively used meadows, extensively grazed pastures). To cover this topic, it is essential to know how much the relatively young wildflower areas contribute to biodiversity compared with well-established extensive meadows and pastures. Total bug species richness and phytophagous bug species richness were significantly higher in wildflower areas and meadows than in pastures. In wildflower areas, we found the highest number of zoophagous bug species and species overwintering in the egg-stage. Species overwintering as adults were most abundant in meadows. Total number of bug species as well as species richness in either trophic groups and overwintering strategies were significantly positively correlated with vegetation structure. Except for overwintering strategies, the same was true to bug abundance. The bug community based on the number of individuals per species was significantly explained by flower abundance and vegetation structure, accounting for 18.4 and $16.8 \%$ of the variance, respectively. Our results indicate that vegetation structure and flower abundance are key factors for bug species richness, abundance and bug species composition. Since wildflower areas and meadows clearly increased bug species richness and contained several specialised bug species that did not occur in pastures, we recommend the promotion of wildflower areas and extensively used meadows in order to restore both high heteropteran diversity and overall insect biodiversity in agricultural landscapes.
\end{abstract}

\section{Introduction}

In recent decades a dramatic decrease of biological diversity in European agricultural landscapes can be observed (Edwards et al. 1999; Marshall and Moonen 2002). The rapid decline in plant and animal species diversity in modern agricultural landscapes can be explained by two main causes. Firstly, most species disappear from agroecosystems due to habitat destruction by increased farming intensity, a deterministic cause of extinction (Tscharntke and Kruess 1999). Secondly, reductions in population size caused by habitat fragmentation lead to further stochastic species losses (Baur and Erhardt 1995; Steffan-Dewenter and Tscharntke 2000). European countries are dominated by 
agricultural landscapes (Jedicke 1994). Therefore, habitat management schemes in these areas have a particularly high potential to restore overall biodiversity and enable the survival of many species in modern cultivated landscapes. Invertebrates play an important role as major contributors to total biodiversity on farmland and as food for vertebrates, such as farmland birds (Fuller et al. 1995; McCracken and Bignal 1998). In response to an increasing awareness of the rapid decline of biological diversity, several approaches are currently being introduced to reduce this process. Since 1993, Swiss farmers have been financially supported to maintain ecological compensation areas such as wildflower areas, extensively managed grasslands, hedges or orchards (Ullrich and Edwards 1999). Such non-cropped areas provide food resources, shelter and hibernation sites for insects and spiders which make different demands on their habitat (Lagerlöf and Wallin 1993; Steffan-Dewenter and Tscharntke 1997; Frank 1999; Keller and Häni 2000). Considering the differential habitat use of arthropods means that only a mosaic of different habitats can guarantee high species diversity in the agricultural landscape (Greiler 1994; Duelli and Obrist 2003). The purpose of ecological compensation areas is not only to enhance biodiversity in intensively used arable land, but also to increase the numbers of natural enemies of herbivores that feed on arable crops and their potential for natural pest control (Thomas et al. 2001; Barone and Frank 2003). Because every habitat type has specific structural characteristics we assume that various habitat types contain differential insect communities. Consequently, the creation of different kinds of compensation areas is desirable to achieve high insect biodiversity. In this study three types of semi-natural habitats are explored, namely wildflower areas, extensively used meadows and extensively grazed pastures. Wildflower areas (a term synonymous with wildflower or weed strips) were developed in the late 1980s, thereby being a relatively young type of ecological compensation area on Swiss farmland (Nentwig 1988). The number of wildflower areas is continuously growing and this type of semi-natural area was previously shown to enhance species richness and abundance of arthropods remarkably (e.g. Lys and Nentwig 1992; Frank 1998). While wildflower areas turned out to be important habitats for encouraging arthropod diversity, nothing is known about how much they contribute to biodiversity compared with well-established compensation areas such as extensively used meadows and extensively grazed pastures. Such meadows and pastures are well-tried types of ecological compensation areas being more common than wildflower areas. Extensive use of meadows and pastures is known to increase overall diversity of insects, including heteropteran bugs (Morris 2000; Di Giulio et al. 2001; Kruess and Tscharntke 2002).

Tscharntke and Greiler (1995) showed that invertebrate diversity in grassland ecosystems could be predicted by using botanical parameters such as floral diversity or other characteristics of vegetation structure. Considering the influence of environmental parameters (plant species richness, vegetation structure, flower abundance, field size, surrounding landscape structure) on insect diversity in different semi-natural habitats appears to be useful to 
quantify the effect of measures enhancing biodiversity in the agricultural landscape. True bugs (Heteroptera) were chosen as an indicator group for insect diversity because they are an ecologically very diverse group, including phytophagous and zoophagous species as well as generalists and specialists (Dolling 1991). Furthermore both larvae and adults live in the same habitat and react sensitively to environmental changes (Morris 1969, 1979; Otto 1996). Additionally, bug species richness was found to correlate strongly with total arthropod richness in cultivated landscapes, making bugs an excellent group for biodiversity evaluation (Duelli and Obrist 1998).

The objectives of our investigation were (i) to show whether bug species richness, abundance and assemblages differ significantly among wildflower areas, extensively used meadows and pastures, and (ii) to determine common key factors significantly influencing bug species richness, abundance and the bug community based on the number of individuals per species. It is essential to know how much each type of semi-natural habitat contributes to heteropteran diversity in agroecosystems, particularly in terms of the comparison between the newly established wildflower areas with the well-tried extensive meadows and pastures. This knowledge can be used as a tool to make recommendations about which types of ecological compensation areas should particularly be promoted.

\section{Material and methods}

\section{Research area and study sites}

The study was carried out from the end of May to the end of September 2002 in the western part of Bern, an intensively used arable region in Switzerland. The area containing the study sites measured about $9 \mathrm{~km}^{2}$. Three types of seminatural habitats were studied (wildflower areas, extensively used meadows, extensively grazed pastures), using five replicates for each habitat type. Wildflower areas have a minimum width of $3 \mathrm{~m}$ and are sown with a standard wildflower mixture of indigenous arable weeds, meadow and ruderal plant species (Günter 2000). They are maintained for at least 2 years and a maximum of 6 years and the use of pesticides and fertilisers is not allowed. From the second year on, one half of the area may be mown in a yearly rotation after the flowering period. Extensively used meadows are sown with a standard mixture consisting of $95 \%$ grass and 5\% herb seeds. No fertilisers and pesticides are allowed. Extensively used meadows have to be mown at least once a year but not before 15 June. The five meadows surveyed were mown twice in the sampling period. The five wildflower areas and the five meadows were sown in spring 1999. The five pastures studied were extensively managed since spring 1999 , the time before they were managed intensively. Mean grazing intensity in the extensively used pastures surveyed was $2.7 \pm 0.2$ cattle ha $^{-1}$. Except for cow-pats, usage of additional fertilisers and pesticides is prohibited (Charollais 
et al. 1999). Wildflower areas were dominated by Achillea millefolium, $H y$ pericum perforatum, Leucanthemum vulgare, Origanum vulgare, Pastinaca sativa and Tanacetum vulgare. Plants with a high coverage in meadows were Centaurea jacea, Leucanthemum vulgare, Trifolium pratense and the grasses Dactylis glomerata and Trisetum flavescens. In pastures, the same grasses as in the meadows were dominant. Pastures were further dominated by Trifolium repens and Taraxacum officinale. The 15 study sites were selected to lie in the same climate zone providing similar site conditions in terms of mean annual rainfall, temperature and altitude, which was about $600 \mathrm{~m}$ a.s.l. The size of the study sites ranged from 0.05 to 0.4 ha.

\section{Sampling methods and bug parameters}

Between the end of May and the end of September 2002, six samples were taken from each study site every 2 or 3 weeks. Sampling was only carried out when the weather conditions were favourable for bug activity, i.e. air temperature of minimum $17{ }^{\circ} \mathrm{C}$, sunshine, dry vegetation and moderate air conditions. Sampling was restricted to the period between 9.30 a.m. and 17.00 p.m., and the sampling order of the study sites varied between sampling dates. The heteropteran bugs were collected using a standardised sweep-net method (Otto 1996). The sweep-net had a diameter of $40 \mathrm{~cm}$ and was fitted with a heavy cloth suitable for use in dense vegetation. For each sample, 100 sweeps were made at a constant pace over a transect of about $80 \mathrm{~m}$. The net was emptied after every 25th sweep, resulting in four subsamples per site at each sampling date. Afterwards, the four subsamples were pooled and insects were killed immediately with ethyl acetate $\left(\mathrm{C}_{4} \mathrm{H}_{8} \mathrm{O}_{2}\right)$. For data analysis, bug abundance (total number of adults and larvae per site) and bug species richness (total number of adult bug species per site) were used. Moreover, two functional groups were analysed considering the trophic level and the overwintering strategy of bugs, by separating into zoophagous (including zoophytophagous species) and phytophagous species, as well as species overwintering as eggs and species overwintering as adults. The adult bugs were determined with the help of entomological handbooks and publications (Wagner 1952, 1966, 1967, 1970-1975; Péricart 1983, 1984, 1987, 1998) and the nomenclature followed Günther and Schuster (2000). Larvae were only counted, but not determined to species level.

\section{Environmental factors}

To examine the influence of vegetation factors on bug species richness, bug abundance and bug communities, plant species richness, flower abundance and vegetation structure were analysed. Plant species richness was surveyed once in June 2002 based on five $1 \mathrm{~m}^{2}$ plots randomly chosen in every site. Vegetation 
structure and flower abundance were analysed six times during the bug sampling period. The sampling locations were ordered every $2 \mathrm{~m}$ along a transect of $50 \mathrm{~m}$, resulting in 26 replicates per sampling date. These $50 \mathrm{~m}$ transects were located in the transects where the heteropteran bugs were collected. Flower abundance was estimated in a $30 \mathrm{~cm} \times 30 \mathrm{~cm}$ square using the following scale: $0=0$ flowers, $1=1-25,2=26-50,3=51-75,4=76-100,5=$ $>100$ flowers $/ 900 \mathrm{~cm}^{2}$. To investigate the vegetation structure, a simplified version of the point quadrat method was used (Künzle 2002): (a) the sampling was carried out along a transect, (b) instead of a needle a $150 \mathrm{~cm}$ long iron rod measuring $8 \mathrm{~mm}$ in diameter was used and (c) individual plant species were not taken into account. The iron rod was marked at the heights of $15 \mathrm{~cm}$ (soil level), $55 \mathrm{~cm}$ (40 cm mark), $95 \mathrm{~cm}$ ( $80 \mathrm{~cm}$ mark) and $135 \mathrm{~cm}$ (120 cm mark). It was put $15 \mathrm{~cm}$ vertically into the soil and every part of a plant, which was in contact with the rod, was counted for each height level separately. For data analysis, however, the arithmetic mean (mean number of plant parts touching the iron rod up to the height of $120 \mathrm{~cm}$ ) of six subsamples with 26 replicates each was used. Field size and the surrounding landscape structure were calculated using a 1:5000 map. The surrounding landscape structure was surveyed within a square by measuring the area of natural landscape in the surrounding of $300 \mathrm{~m}$ width of each site, thereby considering the dispersal range of heteropteran bugs inhabiting open land (Ullrich and Edwards 1999). In this area the environment was separated into two habitat types: natural landscape (extensively managed meadows and pastures, wildflower areas, ruderal sites, orchards, hedges, woodlands) and others (intensively managed arable land, roads, buildings). None of the surroundings of different study sites did overlap. Field size and percentage of natural landscape structure were used for statistical analyses.

\section{Statistical analyses}

For the analysis of the data, all samples were pooled over time, resulting in one sample per site. Flower abundance and vegetation structure were logarithmic and percentage of natural landscape structure was square root transformed to achieve normal distribution and homogeneity of residuals (Zar 1996). Percentage data were also arcsine transformed. However, for analysis we used square root transformed data, because percentage data were better normally distributed when square root transformed. Bug data were transformed as necessary (for details see Section Result). One-way-ANOVA was performed using the program Systat 10.0 to ascertain differences in bug species richness and abundance as well as differences in environmental factors between the three habitat types. The Tukey-test was carried out for multiple comparisons. To examine the influence of environmental factors on bug species richness and abundance, multiple stepwise linear regression models (backward option) were calculated using the program Systat 10.0. Curve estimations were used to test 
for best fitting curves of the most explanatory factors using the program SPSS 11.0. In addition to ANOVA and regression models, where only one single value like species richness or abundance is analysed, canonical correspondence analysis (CCA) and correspondence analysis (CA) were calculated using the programme Canoco 4.5 (Ter Braak and Smilauer 2002). Using CCA and CA, the whole bug community was characterised based on the number of individuals per species and site. Species represented by less than five individuals and occurring in only one site were omitted to reduce noise (Voigt et al. 2003). CCA and CA were performed using $\log (x+0.1)$-transformed species data in order to prevent high values from unduly influencing the ordination and to consider zero values. Ordination by CCA was calculated to analyse the influence of environmental factors on the bug community. The significance for each factor in the CCA was obtained by a Monte Carlo test run with 499 permutations. Ordination by CA was used to compare the similarity of the bug species assemblages among the three habitat types.

\section{Results}

Bug abundance and species richness in the three habitat types

Altogether we recorded 5029 individuals consisting of 1554 adults and 3476 larvae of 75 bug species. In wildflower areas, we observed 69 species and 1820 individuals (639 adults, 1181 larvae). In meadows, there were 53 species and 1523 individuals (468 adults, 1055 larvae) and 31 species and 1686 individuals (447 adults, 1239 larvae) in pastures. Seventy per cent of all adult individuals and 28 species belonged to the Miridae, which were the dominating family in all habitat types (Table 1). Seventy-two per cent of all recorded species and $85.5 \%$ of the adult individuals were phytophagous, whereas the minority were zoophagous or zoophytophagous, mainly Nabidae and Anthocoridae. Percentages of phytophagous individuals were rather equal in all three habitat types, but percentages of phytophagous species were lower in wildflower areas $(69.4 \%)$ than in meadows and pastures $(77 \%)$. Considering the overwintering strategy, $72 \%$ of the observed species and $66 \%$ of all individuals belonged to bugs overwintering as adults. $12.9 \%$ of the species and $20.4 \%$ of the individuals collected in pastures overwinter in the egg-stage. In wildflower areas $30.6 \%$ and in meadows $20.7 \%$ of the species belonged to bugs overwintering as eggs, and percentages of individuals overwintering as eggs were also higher in wildflower areas $(42.9 \%)$ than in meadows $(34.1 \%)$.

The number of bug individuals overwintering in the egg-stage was significantly higher in wildflower areas than in pastures (Figure 1a). By contrast, no differences were found in individuals overwintering as adults, in either trophic group, and in total bug abundance. The total number of bug species in wildflower areas and meadows was significantly higher than in pastures (Figure 1b). The same was true to phytophagous bug species (Figure 1c). For 
Table 1. Bug families in terms of total numbers of species (sp) and adult individuals (ind) occurring in all sites and in three types of semi-natural habitats, and percentage of individuals per sum.

\begin{tabular}{|c|c|c|c|c|c|c|c|c|c|c|c|c|}
\hline \multirow[t]{2}{*}{ Family } & \multicolumn{3}{|c|}{$\begin{array}{l}\text { All sites } \\
(n=15)\end{array}$} & \multicolumn{3}{|c|}{$\begin{array}{l}\text { Wildflower areas } \\
(n=5)\end{array}$} & \multicolumn{3}{|c|}{$\begin{array}{l}\text { Meadows } \\
(n=5)\end{array}$} & \multicolumn{3}{|c|}{$\begin{array}{l}\text { Pastures } \\
(n=5)\end{array}$} \\
\hline & $\mathrm{sp}$ & ind & $\%$ & $\mathrm{sp}$ & ind & $\%$ & $\mathrm{sp}$ & ind & $\%$ & $\mathrm{sp}$ & ind & $\%$ \\
\hline Alydidae & 1 & 2 & 0.1 & 0 & 0 & 0.0 & 1 & 2 & 0.4 & 0 & 0 & 0.0 \\
\hline Anthocoridae & 4 & 17 & 1.1 & 4 & 14 & 2.2 & 2 & 2 & 0.4 & 1 & 1 & 0.2 \\
\hline Berytidae & 1 & 6 & 0.4 & 0 & 0 & 0.0 & 1 & 4 & 0.9 & 2 & 2 & 0.5 \\
\hline Coreidae & 2 & 7 & 0.5 & 2 & 5 & 0.8 & 1 & 2 & 0.4 & 0 & 0 & 0.0 \\
\hline Lygaeidae & 9 & 27 & 1.7 & 6 & 11 & 1.7 & 5 & 9 & 1.9 & 7 & 7 & 1.6 \\
\hline Miridae & 28 & 1087 & 69.9 & 19 & 404 & 63.2 & 20 & 318 & 68.0 & 13 & 365 & 81.6 \\
\hline Nabidae & 8 & 191 & 12.3 & 8 & 81 & 12.7 & 6 & 64 & 13.7 & 5 & 46 & 10.3 \\
\hline Pentatomidae & 9 & 66 & 4.3 & 6 & 17 & 2.6 & 6 & 39 & 8.3 & 4 & 10 & 2.2 \\
\hline Piesmatidae & 1 & 8 & 0.5 & 0 & 0 & 0.0 & 1 & 7 & 1.5 & 1 & 1 & 0.2 \\
\hline Pyrrhocoridae & 1 & 8 & 0.5 & 0 & 0 & 0.0 & 0 & 0 & 0.0 & 1 & 8 & 1.8 \\
\hline Rhopalidae & 5 & 121 & 7.8 & 23 & 106 & 16.6 & 5 & 13 & 2.8 & 1 & 2 & 0.5 \\
\hline Saldidae & 1 & 2 & 0.1 & 1 & 1 & 0.2 & 1 & 1 & 0.2 & 0 & 0 & 0.0 \\
\hline Scutelleridae & 2 & 5 & 0.3 & 0 & 0 & 0.0 & 2 & 5 & 1.1 & 0 & 0 & 0.0 \\
\hline Tingidae & 3 & 7 & 0.5 & 0 & 0 & 0.0 & 2 & 2 & 0.4 & 1 & 5 & 1.1 \\
\hline Sum & 75 & 1554 & 100 & 69 & 639 & 100 & 53 & 468 & 100 & 31 & 447 & 100 \\
\hline
\end{tabular}

Numbers refer to six samples per site. $n=$ number of sites per habitat type.

zoophagous species and species overwintering as eggs, significantly larger numbers were observed in wildflower areas compared to pastures (Figures 1d, e). Meadows contained significantly more species overwintering as adults than pastures (Figure 1f).

\section{Factors explaining bug abundance and species richness}

We tested the influence of five environmental factors on bug species richness and abundance using stepwise multiple regression. The variability of adult individuals (Figure 2a), total bug abundance $\left(y=509.001 \log x^{1.97}, F=5.53\right.$, $R^{2}=0.299, p=0.035, n=15$ ), and the number of phytophagous individuals $\left(\sqrt{ } y=12.465 \log x^{1.28}, F=10.91, R^{2}=0.456, p=0.006, n=15\right)$ and zoophagous individuals $\left(\sqrt{ } y=5.432 \log x^{2.02}, F=7.64, R^{2}=0.37, p=\right.$ $0.016, n=15)$ were best explained by vegetation structure. There was a significant negative relation between individuals overwintering as adults and surrounding landscape structure in a perimeter of $300 \mathrm{~m}$, which accounted for $55.5 \%$ of the variance (Figure $2 b$ ). The distribution of bug individuals that are overwintering as eggs was best explained by a negative relationship with field size accounting for $69.3 \%$ of the variance (Figure 2c). Total bug species richness and phytophagous bug species increased significantly with vegetation structure, which explained $40.2 \%$ (Figure 2d) and $54.5 \%$ (Figure 2e) of the variance, respectively. Also the variability of zoophagous bug species 
(a) Log number of individuals overwintering as eggs

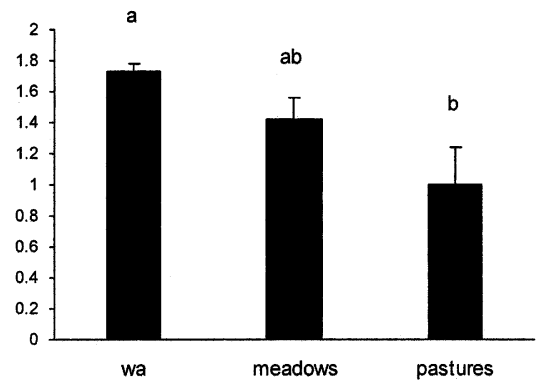

(c) Log number of phytophagous species

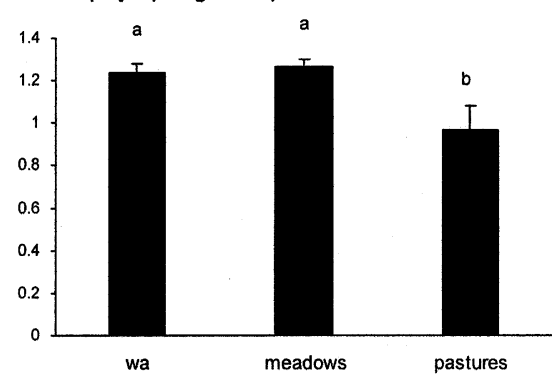

(e) Number of species overwintering as eggs

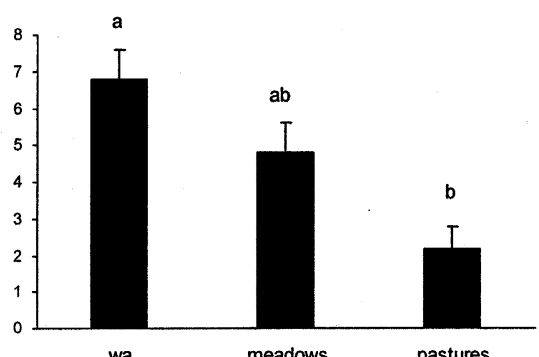

(b) Number of species

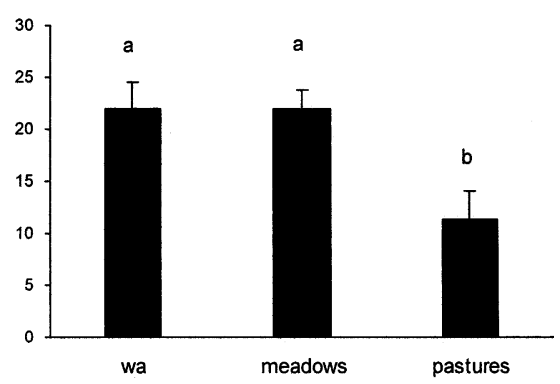

(d) Number of zoophagous species

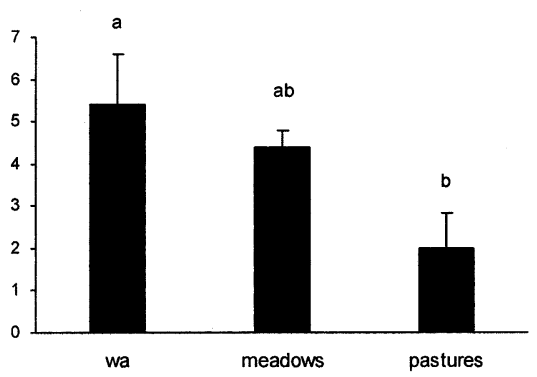

(f) Log number of species overwintering as adults

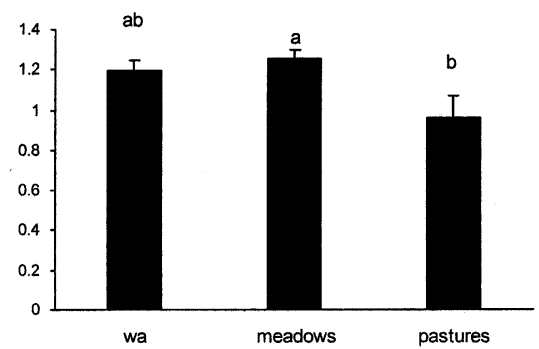

Figure 1. Distribution of bug individuals and bug species (mean $\pm \mathrm{SE}$ ) in wildflower areas (wa), meadows and pastures. Different letters above bars indicate significant differences between habitat types (Tukey test, $p<0.05$ ). (a) Number of individuals overwintering in the egg-stage (logarithmic transformed): ANOVA, $F=5.137, p=0.024, n=15$. (b) Number of bug species: $F=6.704$, $p=0.011, n=15$. (c) Number of phytophagous bug species (logarithmic transformed): $F=5.496$, $p=0.020, n=15$. (d) Number of zoophagous bug species: $F=3.948, p=0.048, n=15$. (e) Number of bug species overwintering as eggs: $F=9.852, p=0.003, n=15$. (f) Number of bug species overwintering as adults (logarithmic transformed): $F=4.536, p=0.034, n=15$.

$\left(y=-5.299+12.178 \log x, F=13.618, R^{2}=0.512, p=0.003, n=15\right)$, species overwintering as adults $\left(y=-2.133+8.037 \log x-4.766 \log x^{2}\right.$, $\left.F=6.92, R^{2}=0.535, p=0.01, n=15\right)$ and species overwintering as eggs 

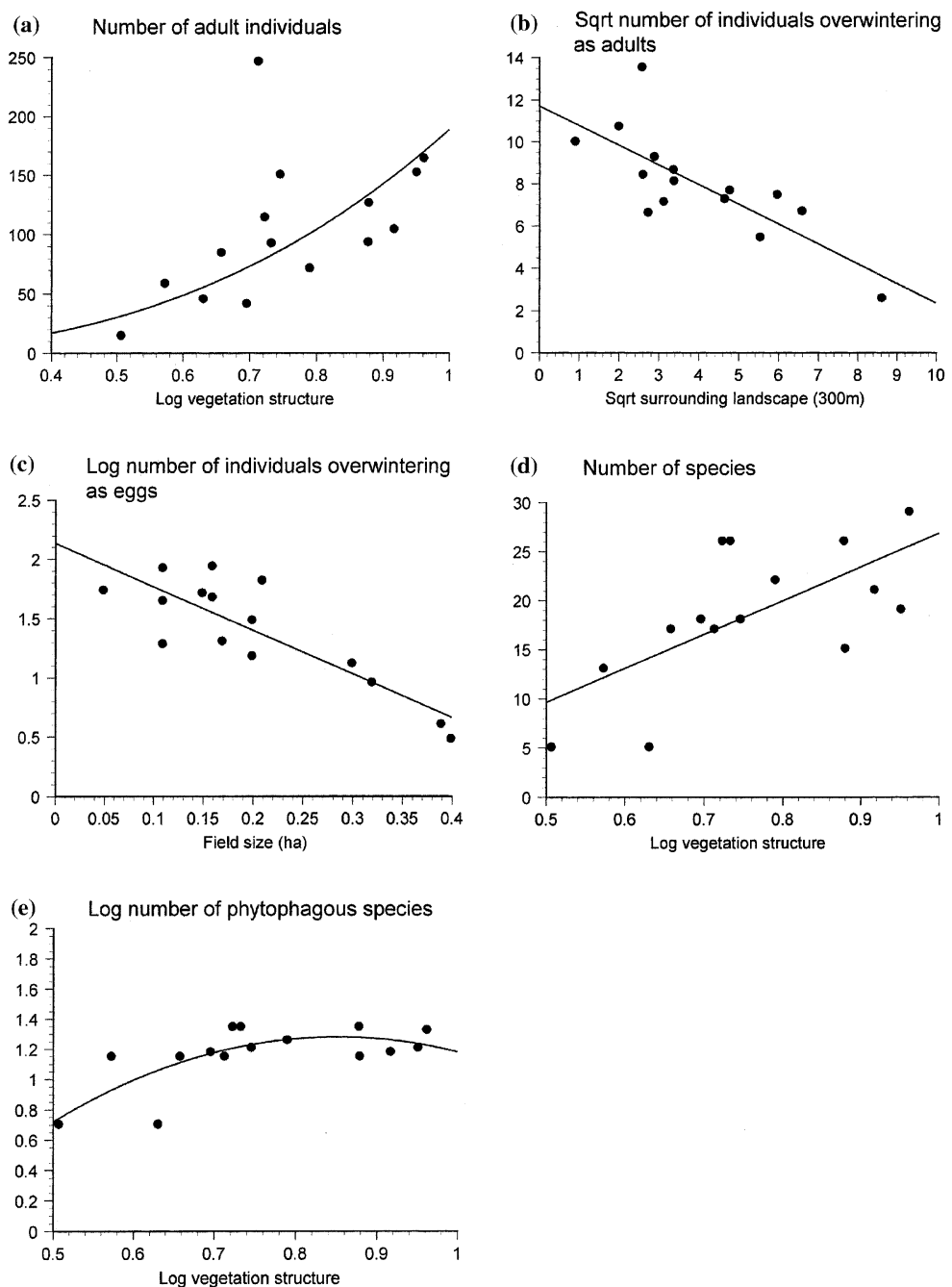

Figure 2. Effects of environmental factors on bug abundance and bug species richness. (a) Relation between number of adult individuals and vegetation structure: $y=188.12 \log x^{2.67}, F=13.52$, $R^{2}=0.51, p=0.003, n=15$. Vegetation structure is logarithmic transformed. (b) Negative relation between number of individuals overwintering as adults and surrounding landscape: $\sqrt{ } y=11.696-0.965 \sqrt{ } x, F=18.451, R^{2}=0.591, p=0.001, n=15$. Surrounding landscape and individuals overwintering as adults are square root transformed. (c) Negative relation between number of individuals overwintering as eggs and field size (ha): $\log y=2.132-0.037 x, F=32.582$, $R^{2}=0.715, p<0.001, n=15$. Individuals overwintering as eggs are logarithmic transformed. (d) Relation between total number of bug species and vegetation structure: $y=-7.667+34.47 \log x$, $F=10.396, R^{2}=0.444, p=0.007, n=15$. Vegetation structure is logarithmic transformed. (e) Relation between number of phytophagous bug species and vegetation structure: log $y=-2.0132+7.7209 \log x-4.5299 \log x^{2}, F=7.19, R^{2}=0.545, p=0.009, n=15$. Vegetation structure and phytophagous bug species richness are logarithmic transformed. 
$\left(y=-5.777+13.687 \log x, F=18.017, R^{2}=0.581, p=0.001, n=15\right)$ were best explained by vegetation structure. Whereas total species richness, zoophagous species and species overwintering as eggs showed a continous increase with progressing vegetation structure (linear model), phytophagous species and species overwintering as adults were saturated at a certain level of vegetation structure (quadratic model), suggesting that these bug features would not increase with additional vegetation structure.

Environmental factors surveyed showed different patterns between the three habitat types. Flower abundance was significantly higher in wildflower areas than in meadows and pastures (Tukey, $p<0.005$ ). Vegetation structure increased significantly from pastures to meadows and wildflower areas $(p<0.05)$, and pastures were significantly larger in size than wildflower areas $(p<0.005)$. Plant species richness and surrounding landscape structure in a perimeter of $300 \mathrm{~m}$ to the study sites showed no significant differences between the three habitat types. Since vegetation structure and field size differed significantly among habitat types and revealed significant relations with certain bug features, we tested whether these relations were caused by habitat effect rather than by an environmental factor. For that, we calculated multiple regression models where habitat types were dummy coded using meadows as a basis. Only in two of nine regression models (relation between adult bug individuals and vegetation structure, and relation between bug species overwintering as adults and vegetation structure) was there a significant habitat effect, but always explaining less variance than vegetation structure. Accordingly, significant relations found were predominantly due to the environmental factor, and only two relations were caused by both the environmental factor (vegetation structure) plus habitat effect.

\section{Factors influencing bug communities}

The bug community was examined relative to environmental factors using canonical correspondence analysis (CCA), which explained $44.2 \%$ of the total variance. Of the five environmental factors considered, only flower abundance contributed significantly to the distribution of heteropteran bugs accounting for $18.4 \%$ of the variance. The remaining variance was explained by the other factors (Table 2). A further CCA model excluding flower abundance, which was highly correlated with vegetation structure (Spearman's $r_{\mathrm{s}}=0.861$, $p<0.001, n=15$ ), explained $36.7 \%$ of the total variance of the bug community. In this model vegetation structure was the only significant factor accounting for $16.8 \%$ of the variance. The same results were obtained when CCA models were analysed including also the rare species with less than five individuals. A group of species (Aelia acuminata, Dicyphus globulifer, Stictopleurus punctatonervosus, Capsus ater, Megalocoleus molliculus, Plagiognathus arbustorum) was preferentially or exclusively found in wildflower areas (Table 3) and strongly correlated with flower abundance and vegetation 
Table 2. Canonical correspondence analyses (CCA) including all environmental factors and without flower abundance, showing variance explained by each environmental factor and Monte Carlo procedure with 499 permutations.

\begin{tabular}{llll}
\hline Environmental factor & Variance & & \\
\cline { 2 - 4 } & Explained (\%) & $p$-Value & -ratio \\
\hline All factors & & & 2.93 \\
Flower abundance & 18.4 & 0.002 & 1.26 \\
Plant species richness & 7.7 & 0.180 & 1.16 \\
Vegetation structure & 6.9 & 0.278 & 1.01 \\
Field size & 6.1 & 0.498 & 0.80 \\
Surrounding landscape $300 \mathrm{~m}$ & 4.6 & 0.696 & 2.63 \\
Without flower abundance & & & 1.28 \\
Vegetation structure & 16.8 & 0.002 & 0.98 \\
Plant species richness & 7.6 & 0.182 & 0.91 \\
Field size & 6.1 & 0.522 & 0.560 \\
Surrounding landscape $300 \mathrm{~m}$ & 6.1 & & \\
\hline
\end{tabular}

structure (Figure 3). Notostira elongata, Peritrechus geniculatus, Kalama tricornis, Piesma maculatum and Stenodema laevigata revealed an opposite distribution. They were most abundant in pastures or meadows, and some of them were completely absent from wildflower areas (Table 3). Species correlated with plant species richness (Orius niger, Himacerus mirimicoides, Rhyparochromus pini, Eysarcoris aeneus, Adelphocoris seticornis) dominated in wildfower areas or meadows and were absent from pastures.

\section{Characterisation of the habitat types}

In the correspondence analysis (CA) the cumulative percentage explained by the first two axes was $36.2 \%$. CA exhibited distinct clustering of the three habitat types. Except for one site, the bug community within the wildflower areas was very similar but clearly separated by axis 2 from communities of meadows and pastures. Bug species assemblages of pastures and wildflower areas were most separated, while meadows were more similar to pastures (Figure 4).

\section{Discussion}

The dominance of the bug families Miridae, Nabidae and Rhopalidae sampled by sweep-netting in our study is typical for semi-natural habitats in cultivated landscapes (Künzle 2002). Wildflower areas were characterised by oligophagous mirid species and mirids overwintering as eggs, and the rhopalid $S$. punctatonervosus. In meadows and pastures we recorded more generalists and species overwintering as adults and bivoltine species such as the mirids 


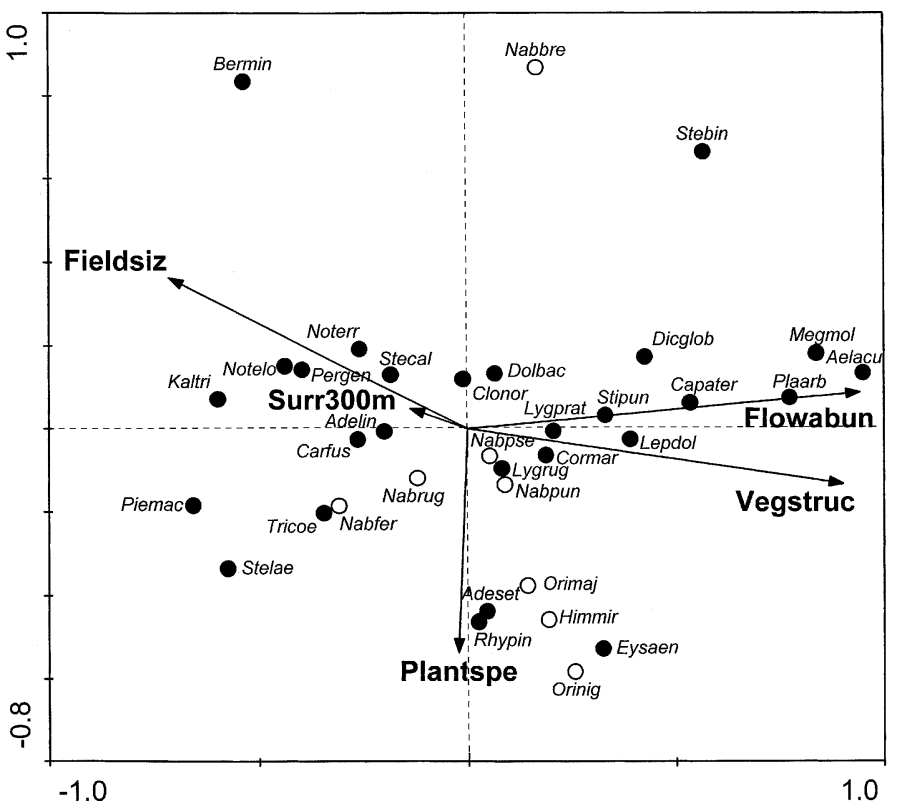

Figure 3. Canonical correspondence analysis (CCA) based on the most abundant phytophagous $(\mathbf{O})$ and zoophagous $(\mathrm{O})$ bug species, showing axes 1 and 2. Environmental factors are displayed as vectors. Abbreviations of bug species: Adelin, Adelphocoris lineolatus Gz.; Adeset, Adelphocoris seticornis F.; Aelacu, Aelia acuminata L.; Bermin, Berytinus minor H.-S.; Clonor, Closterotomus norvegicus Gm.; Capate, Capsus ater L.; Carfus, Carpocoris fuscispinus Boh.; Cormar, Coreus marginatus L.; Dicglo, Dicyphus globulifer Fall.; Dolbac, Dolycoris baccarum L.; Eysaen, Eysarcoris aeneus Scop.; Himmir, Himacerus mirmicoides O.C; Kaltri, Kalama tricornis Schrank; Lepdol, Leptopterna dolobrata L.; Lygpra, Lygus pratensis L.; Lygrug, Lygus rugulipennis Popp.; Megmol, Megalocoleus molliculus Fall.; Nabbre, Nabis brevis Sz; Nabfer, Nabis ferus L.; Nabpse, Nabis pseudoferus Rem.; Nabpun, Nabis punctatus AC.; Nabrug, Nabis rugosus L.; Notelo, Notostira elongata Geoffr.; Noterr, Notostira erratica L.; Orimaj, Orius majusculus Reut; Orinig, Orius niger Wff; Pergen, Peritrechus geniculatus Hahn; Piemac, Piesma maculatum Lap.; Plaarb, Plagiognathus arbustorum F.; Rhypin, Rhyparochromus pini L.; Stebin, Stenotus binotatus F.; Stecal, Stenodema calcarata Fall.; Stelae, Stenodema laevigata L.; Stipun, Stictopleurus punctatonervosus Gz.; Tricae, Trigonotylus caelestialium Kirk.

N. elongata, N. erratica and L. rugulipennis (Wagner 1952, 1966; Rieger 1978). Nabid species reached moderate abundances in all habitat types.

Our results clearly showed that total bug species richness and richness of both functional groups were usually lower in pastures than in wildflower areas and meadows. Except for individuals overwintering as eggs, however, numbers of individuals were never significantly different between any habitat type. CA revealed that the species composition of pastures was quite similar to that of meadows, but clearly separated from communities in wildflower areas. In all situations but two (individuals overwintering as adults and eggs), vegetation structure was the best explanatory factor for the distribution of bug species richness and abundance. Among the factors analysed, flower abundance and 
Table 3. Number of individuals of the 35 most abundance bug species in the three habitat types.

\begin{tabular}{|c|c|c|c|c|c|}
\hline Species & Family & $\begin{array}{l}\text { Wildflower } \\
\text { Areas }\end{array}$ & Meadows & Pastures & Total \\
\hline Adelphocoris lineolatus $\mathrm{Gz}$. & Miridae & 28 & 10 & 13 & 51 \\
\hline Adelophocoris seticornis $\mathrm{F}$. & Miridae & 2 & 8 & 0 & 10 \\
\hline Aelia acuminate $\mathrm{L}$. & Pentatomidae & 5 & 0 & 3 & 8 \\
\hline Berytinus minor H.S & Berytidae & 0 & 4 & 2 & 6 \\
\hline Capsus ater $\mathrm{L}$. & Miridae & 74 & 0 & 0 & 74 \\
\hline Carpocoris fuscispinus Boh. & Pentatomidae & 2 & 29 & 5 & 36 \\
\hline Closterotomus norewegicus $\mathrm{Gm}$. & Miridae & 44 & 110 & 12 & 166 \\
\hline Coreus marginatus $\mathrm{L}$. & Coreidae & 4 & 2 & 0 & 6 \\
\hline Dolycoris baccarum $\mathrm{L}$. & Pentatomidae & 3 & 4 & 1 & 8 \\
\hline Dicyphus globulifer Fail. & Miridae & 92 & 1 & 2 & 95 \\
\hline Eysarcoris aeneus Scop. & Pentatomidae & 4 & 1 & 0 & 5 \\
\hline Himacerus mirmicoides $\mathrm{O}$. Costa & Nabidae & 8 & 4 & 0 & 12 \\
\hline Kalama tricornis Schrank & Tingidae & 0 & 1 & 4 & 5 \\
\hline Leptoptema dolobrate $\mathrm{L}$. & Miridae & 40 & 5 & 0 & 45 \\
\hline Lygus Pratenis $\mathrm{L}$. & Miridae & 11 & 8 & 1 & 20 \\
\hline Lygus rugulipennis Popp. & Miridae & 18 & 26 & 4 & 48 \\
\hline Megalocoleus molliculus Fall. & Miridae & 30 & 0 & 0 & 30 \\
\hline Nabis breve Sz. & Nabidae & 9 & 1 & 6 & 16 \\
\hline Nabis ferus L. & Nabidae & 9 & 19 & 13 & 41 \\
\hline Nabis pseudoferus Rem. & Nabidae & 33 & 12 & 16 & 61 \\
\hline Nabis punctatus A. Costa & Nabidae & 10 & 25 & 2 & 37 \\
\hline Nabis rugosus $\mathrm{L}$. & Nabidae & 4 & 3 & 9 & 16 \\
\hline Notostira elongatea Geoffr & Miridae & 6 & 58 & 190 & 254 \\
\hline Notostria erratica $\mathrm{L}$. & Miridae & 14 & 27 & 62 & 103 \\
\hline Orius majusculus Reut. & Anthocoridae & 6 & 1 & 1 & 8 \\
\hline Orius niger Wff. & Anthocoridae & 4 & 1 & 0 & 5 \\
\hline Peritrechus geniculatus Hahn & Lygaeidae & 1 & 1 & 6 & 8 \\
\hline Piesma maculatum Lap. & Piesmatidae & 0 & 7 & 1 & 8 \\
\hline Plagiognathus arbustorum $\mathrm{F}$. & Miridae & 23 & 0 & 0 & 23 \\
\hline Rhyparochromus pini $\mathrm{L}$. & Lygaeidae & 4 & 4 & 0 & 8 \\
\hline Stenodema calcarata Fall. & Miridae & 11 & 11 & 10 & 32 \\
\hline Stenodema laevigata $\mathrm{L}$. & Miridae & 0 & 21 & 3 & 24 \\
\hline Stenotus binotatus $\mathrm{F}$. & Miridae & 3 & 2 & 0 & 5 \\
\hline Stictopleurus punctatonervosus Gz. & Rhopalidae & 104 & 6 & 2 & 112 \\
\hline Trigonotylus caelestialium Kirk. & Miridae & 3 & 22 & 65 & 90 \\
\hline
\end{tabular}

vegetation structure were the factors best explaining bug features. Because flower abundance and vegetation structure were highly correlated, they were representative of each other. Thus, regression and CCA models led to the same pattern, indicating that both vegetation structure and flower abundance were key factors influencing species richness, abundance (regression) and bug species composition (CCA).

Although in previous studies plant species diversity was of high predictive value for arthropod species diversity (Dramstad and Fry 1995; Tscharntke and Greiler 1995; Künzle 2002) and larval survival of plant feeding heteropteran 


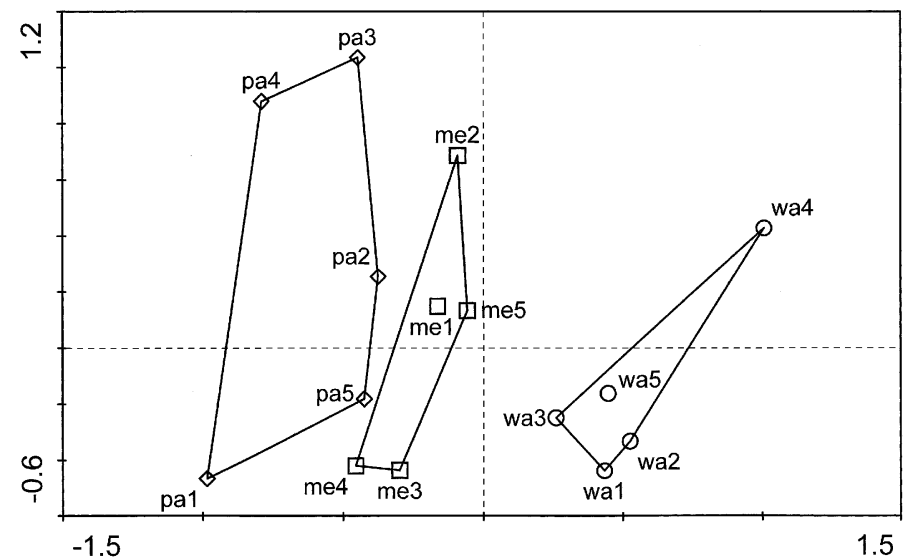

Figure 4. Correspondence analysis (CA) to compare the similarity of bug communities between wildflower areas $(\bigcirc$ wa), meadows $(\square$ me) and pastures $(\diamond$ pa), revealing axes 1 and 2 . The five replicates of each habitat type are enveloped to make similarities among habitat types more apparent.

bugs (Di Giulio and Edwards 2003), in our study vegetation structure expressed by the mean number of plant parts touching a rod was a more important factor for the explanation of bug distribution. Similarly, vegetation cover abundance, a habitat characteristic comparable to vegetation structure of the present study, was observed to be among the best predictors of arthropod abundance (Borges and Brown 2001). Huusela-Veistola and Vasarainen (2000) showed that abundance and species richness of leafhoppers in grass strips seemed to be more dependent on structural diversity of vegetation than on plant species richness per se. Brown et al. (1992) revealed that leafhopper assemblages were strongly affected by plant architecture as determined by grazing treatment, but not by plant species composition except for a few specialists. Intense grazing can reduce arthropod species diversity and abundance (Morris 1967; Gibson et al. 1992; Curry 1994), but it also affects grassland through the selectivity of grass feeding by herbivorous vertebrates, e.g. by locally eliminating vegetation, by causing mini successions, or through trampling and fertilising. These facts influence floral composition, which in turn affects insect communities (Tscharntke and Greiler 1995). Murdoch et al. (1972) showed that ungrazed grasslands supported higher resource heterogeneity for insects than pastures, because vegetation height was greater and thus plant architecture more complex. Kruess and Tscharntke (2002) observed a general trend of higher insect diversity on ungrazed grassland compared with grazed pastures. In contrast to a mown meadow, a lightly grazed pasture is heterogeneous in its vertical vegetation structure. Nevertheless, total bug species, phytophagous bug species and species that are overwintering as adults were more frequent in the meadows than in the pastures. The investigated meadows were cut twice in the sampling period. Perhaps this disturbance by 
immediately removing the vegetation cover was not as big as the more continuous disturbance by grazing. Morris (1979) showed for $N$. elongata that the timing of life cycle in relation to the timing of management is important. $N$. elongata has two generations per year and was therefore less susceptible to cutting than univoltine grassland mirids. Furthermore, $N$. elongata usually was not significantly more common in untreated grassland compared with cut plots. $N$. elongata was the most abundant bug species in our study sites. It reached much higher densities in pastures and meadows than in wildflower areas, which shows that its phenology well fitted to the management regimes and further supports the observations described above.

There were significantly more zoophagous bug species in wildflower areas than in pastures, whereas numbers of zoophagous individuals showed no differences between the habitat types. The reason why we only found differences in species number is due to the fact that several rare species occurred in wildflower areas, but were absent from pastures. In the regression models the variability of both zoophagous bug species and zoophagous individuals were best explained by vegetation structure, which confirms previous findings revealing that zoophagous bug species were positively correlated with vegetation structure (Künzle 2002). Highly structured vegetation supports large insect populations by providing a greater potential surface for colonisation and more resources, such as oviposition, resting and overwintering sites (May 1973; Price et al. 1980; Lawton and Strong 1981; Lawton 1983). These advantages could explain the positive response of zoophagous bug species and individuals to vegetation structure. Due to denser and higher vegetation, predators find more hiding places and cover from their own enemies (Lagerlöf and Wallin 1993; Morris 2000). Furthermore, richly structured habitats are colonised faster by prey populations (White and Hassal 1994), which may favour the nutritional conditions of zoophagous bugs. Although pollen seems of poor value for development and reproduction of bugs, it perhaps represents an indirect cue for finding developing prey populations (Fauvel 1999). Prey populations such as thrips, aphids and psyllids were shown to be attracted by flower abundance (Russel 1989; Fauvel 1999), which was highest in wildflower areas in our study. We found most individuals of the zoophagous bugs $O$. niger, O. majusculus, $H$. mirmicoides and $N$. pseudoferus in wildflower areas.

The abundance of bugs, which are overwintering as eggs, was negatively associated with field size. Our results agree with previous research on Hemiptera (Sanderson 1992) and are supported by a study reflecting high butterfly densities in small habitats as an accumulation of individuals from the surrounding landscape, as these fragments provide the only attractive habitat patches (Steffan-Dewenter and Tscharntke 2000). In our study sites, field size was strongly negatively correlated with vegetation structure (Spearman's $\left.r_{\mathrm{s}}=-0.856, p<0.001, n=15\right)$. This means that the smaller wildflower areas showed a complex vegetation structure in contrast to the larger pastures that featured a low vegetation complexity, indicating that wildflower areas offer better possibilities for laying eggs. One may assume that the negative 
relationship between bug individuals overwintering as eggs and field size was caused by the different vegetation structures in habitat types, rather than by field size. However, partial correlation using vegetation structure as control variable revealed that there was a real relationship between bug individuals overwintering as eggs and field size (partial correlation coefficient $=-0.625$, $p=0.017$ ). Species overwintering as eggs depend on food plants in their overwintering site for development in spring, and thus cannot use annual plants (Wagner 1966; Ullich 2001). This agrees with our study where many host plants of bug species overwintering in the egg-stage, such as Achillea, Tanacetum, other Asteraceae and Urtica, were most abundant in wildflower areas. The amount of natural landscape surrounding a site had a negative effect on bug individuals overwintering as adults. Such individuals can disperse directly after overwintering, thereby being independent of host plants at hibernation sites. Therefore, we assume that bugs overwintering as adults in fairly monotonous areas colonise semi-natural areas where they find more favourable conditions for nutrition and reproduction. However, bugs overwintering in more heterogenous areas may stay there and not colonise our study sites, which may have caused the negative relation between adult overwinterers and surrounding landscape structure.

In the CCA, frequencies of certain bug species were strongly related to vegetation structure and flower abundance, which can be explained by the fact that these two environmental factors were positively correlated. Many species showing a correlation with flower abundance and vegetation structure belonged to the Miridae and were only abundant in wildflower areas. P. arbustorum feeds on Urticaceae, M. molliculus on Tanacetum and Achillea, and D. globulifer on Melandryum. These findings are supported by the fact that they depend on perennial host plants, which almost exclusively occurred in wildflower areas. Leptopterna dolobrata is feeding on grasses (Alopecurus, Dactylis, Phleum). Thus this species would be expected to be more frequent in meadows and pastures where these grasses are common. In former surveys $L$. dolobrata was adversely affected in its abundance by intensive management, thus was reduced by both frequency of cutting and early cuts (Di Giulio et al. 2001). Since the females lay their eggs on the bottom part of grass stems (Kullenberg 1944), damage to the eggs does probably not occur, but larval development may be the critical phase because it takes place in June, when the extensively used meadows were cut. This may have been the reason for very low numbers of $L$. dolobrata in meadows and pastures.

In general, our results indicate that vegetation structure and flower abundance are of high predictive value for bug species richness, abundance and bug species composition. Wildflower areas and extensively used meadows had higher vegetation structure than extensively grazed pastures, and wildflower areas also comprised higher flower abundance compared with pastures. Wildflower areas and extensively used meadows contained a number of specialised bug species, while the pastures were characterised by common and widespread species, which also occurred in meadows or wildflower areas. Since 
wildflower areas and meadows clearly increased total bug species richness and the majority of species occurring in extensively grazed pastures could also be found in the other two habitat types surveyed, we recommend the promotion of wildflower areas and extensively used meadows in order to restore high heteropteran diversity in modern cultivated landscapes. This recommendation is of practical relevance because the semi-natural habitats studied are part of agri-environment schemes supported by the Swiss government and management prescriptions can be modified easily.

\section{Acknowledgements}

We are grateful to J.-P. Airoldi and P. Kehrli for statistical advice. Special thanks to I. Künzle for the help in determining the nabid species and advice in field work, and R. Egli and B. Tschanz for assistance with field work. R. Heckmann checked the determination of critical bug species. Special thanks to P. Borges and W. Rabitsch, and two anonymous referees for critically commenting on the draft version of the manuscript.

\section{References}

Barone M. and Frank T. 2003. Habitat age increases reproduction and nutritional condition in a generalist arthropod predator. Oecologia 135: 78-83.

Baur B. and Erhardt A. 1995. Habitat fragmentation and habitat alterations: principal threats to most animal and plant species. Gaia 4: 221-226.

Borges A.V. and Brown V.K. 2001. Phytophagous insects and web-building spiders in relation to pasture vegetation complexity. Ecography 24: 68-82.

Brown V.K., Gibson C.W.D. and Kathirithamby J. 1992. Community organisation in leaf hoppers. Oikos 65: 87-106.

Charollais M., Kuchen S., Mulhauser G., Schiess-Bühler C. and Schüpbach H. 1999. Wegleitung für den ökologischen Ausgleich auf dem Landwirtschaftsbetrieb. Landwirtschaftliche Beratungszentrale LBL, Lindau.

Curry J.P. 1994. Grassland Invertebrate-ecology, Influence on Soil Fertility and Effects on Plant Growth. Chapman and Hall, London.

Di Giulio M., Edwards P.J. and Meister E. 2001. Enhancing insect diversity in agricultural grasslands: the roles of management and landscape structure. J. Appl. Ecol. 38: 310-319.

Di Giulio M. and Edwards P.J. 2003. The influence of host plant diversity and food quality on larval survival of plant feeding heteropteran bugs. Ecol. Entomol. 28: 51-57.

Dolling W.R. 1991. The Hemiptera. Oxford University Press, Oxford.

Dramstad W. and Fry G. 1995. Foraging activity of bumblebees (Bombus) in relation to flower resources on arable land. Agric. Ecosyst. Environ. 53: 123-135.

Duelli P. and Obrist K.M. 1998. In search for the best correlates for local organismal biodiversity in cultivated areas. Biodivers. Conserv. 7: 297-309.

Duelli P. and Obrist K.M. 2003. Regional biodiversity in an agricultural landscape: the contribution of seminatural habitat islands. Basic Appl. Ecol. 4: 129-138.

Edwards P.J., Kollmann J. and Wood D. 1999. Determinants of agrobiodiversity in the agricultural landscape. In: Wood D. and Lenné J.M. (eds), Agrobiodiversity: Characterization, Utilization and Management. CAB International, CABI Publishing, Wallingford Oxon, pp. 183-210. 
Fauvel G. 1999. Diversity of Heteroptera in agroecosystems: role of sustainability and bioindication. Agric. Ecosyst. Environ. 74: 275-303.

Frank T. 1998. Attractiveness of sown weed strips on hoverflies (Syrphidae, Diptera), butterflies (Rhopalocera, Ledidoptera), wild bees (Apoidea, Hymenoptera) and thread-waisted wasps (Sphecidae, Hymenoptera). Mitt. Schweiz. Entomol. Ges. 71: 11-20.

Frank T. 1999. Density of adult hoverflies (Dipt., Syrphidae) in sown weed strips and adjacent fields. J. Appl. Entomol. 123: 351-355.

Fuller R.J., Gregory R.D., Gibbons D.W., Marchant J.H., Wilson J.D., Baillie S.R. and Carter N. 1995. Population declines and range contractions among farmland birds in Britain. Conserv. Biol. 9: 1425-1441.

Gibson C.W.D., Hambler C. and Brown V.K. 1992. Changes in spider (Araneae) assemblages in relation to succession and grazing management. J. Appl. Ecol. 29: 133-142.

Greiler H.J. 1994. Insektengesellschaften auf selbstbegrünten und eingesäten Ackerbrachen. Agrarökologie 11: 1-136.

Günter M. 2000. Anlage und Pflege von mehrjährigen Buntbrachen unter den Rahmenbedingungen des schweizerischen Ackerbaugebietes. Agrarokölogie 37: 1-154.

Günther H. and Schuster G. 2000. Verzeichnis der Wanzen Mitteleuropas (Insecta: Heteroptera). Mitt. Int. Entomol. Vereins 2: 1-69.

Huusela-Veistola E. and Vasarainen A. 2000. Plant succession in perennial grass strips and effects on the diversity of leafhoppers (Homoptera, Auchenorrhyncha). Agric. Ecosyst. Environ. 80: $101-112$.

Jedicke E. 1994. Biotopverbund. Ulmer, Stuttgart.

Keller S. and Häni F. 2000. Ansprüche von Nützlingen und Schädlingen an den Lebensraum. In: Nentwig W. (ed), Streifenförmige ökologische Ausgleichsflächen in der Kulturlandschaft: Ackerkrautstreifen, Buntbrache, Feldränder. Verlag Agrarökologie, Bern, pp. 199-217.

Kruess A. and Tscharntke T. 2002. Contrasting responses of plant and insect diversity to variation in grazing intensity. Biol. Conserv. 106: 293-302.

Kullenberg B. 1944. Studien über die Biologie der Capsiden. Ph.D. thesis, University of Uppsala. Künzle I. 2002. Early succession of bug communities (Insecta: Heteroptera) on wildflower areas. Diploma thesis, University of Bern.

Lagerlöf J. and Wallin H. 1993. The abundance of arthropods along two field margins with different types of vegetation composition: an experimental study. Agric. Ecosyst. Environ. 43: $141-154$.

Lawton J.H. 1983. Plant architecture and the diversity of phytophagous insects. Ann. Rev. Entomol. 28: 23-39.

Lawton J.H. and Strong D.R.J. 1981. Community patterns and competition in folivorous insects. Am. Nat. 118: 317-338.

Lys J.-A. and Nentwig W. 1992. Augmentation of beneficial arthropods by strip-management. 4. Surface activity, movements and activity density of abundant carabid beetles. Oecologia 92: 373-382.

Marshall E.J.P. and Moonen A.C. 2002. Field margins in Northern Europe: their functions and interactions with agriculture. Agric. Ecosyst. Environ. 89: 5-21.

May R.M. 1973. Stability and Complexity in Model Ecosystems. Princeton University Press, Princeton.

McCracken D.I. and Bignal E.M. 1998. Applying the results of ecological studies to land-use policies and practices. J. Appl. Ecol. 35: 961-967.

Morris M.G. 1967. Differences between the invertebrate faunas of grazed and ungrazed chalk grasslands. I. Responses of some phytophage insects to cessation of grazing. J. Anim. Ecol. 36: 459-474.

Morris M.G. 1969. Differences between the invertebrata faunas of grazed and ungrazed chalk grasslands. III. The heteropterous fauna. J. Appl. Ecol. 6: 475-487.

Morris M.G. 1979. Responses of grassland invertebrates to management of cutting. II. Heteroptera. J. Appl. Ecol. 16: 417-432. 
Morris M.G. 2000. The effects of structure and its dynamics on the ecology and conservation of arthropods in British grasslands. Biol. Conserv. 95: 129-142.

Murdoch W.W., Evans F.C. and Peterson C.H. 1972. Diversity and pattern in plants and insects. Ecology 53: 819-829.

Nentwig W. 1988. Augmentation of beneficial arthropods by strip-management. 1. Succession of predacious arthropods and long-term change in the ratio of phytophagous and predacious arthropods in a meadow. Oecologia 76: 597-606.

Otto A. 1996. Die Wanzenfauna montaner Magerwiesen und Grünbrachen im Kanton Tessin (Insecta, Heteroptera). Ph.D. thesis, ETH, Zürich.

Péricart J. 1983. Hémiptères Tingidae Euro-méditerranéens. Faune de France 69. Fédération Francaise des Sociérés de Sciences Naturelles, Paris.

Péricart J. 1984. Hémiptères Berytidae Euro-méditerranéens. Faune de France 70. Fédération Francaise des Sociérés de Sciences Naturelles, Paris.

Péricart J. 1987. Hémiptéres Nabidae d' Europe Occidental et du Maghreb. Faune de France 71. Fédération Francaise des Sociérés de Sciences Naturelles, Paris.

Péricart J. 1998. Hémiptères Lygaeidae d' Europe Occidental et du Maghreb. Faune de France 84 A, B, C. Fédération Francaise des Sociérés de Sciences Naturelles, Paris.

Price P.W., Bouton C.E., Gross P., McPheron B.A., Thompson J.N. and Weis A.E. 1980. Interactions among three trophic levels, the influence of plants on interactions between insect herbivores and natural enemies. Ann. Rev. Ecol. Syst. 11: 41-65.

Rieger C. 1978. Zur Verbreitung von Trigonotylus coelestialium (Kirklady), 1902. Mitt. Bayer. Entomol. 27: 83-90.

Russel E.P. 1989. Enemies hypothesis: a review of the effect of vegetational diversity on predatory insects and parasitoids. Environ. Entomol. 18: 590-599.

Sanderson R.A. 1992. Diversity and eveness of Hemiptera communities on naturally vegetated derelict land in NW-England. Ecography 15: 154-160.

Steffan-Dewenter I. and Tscharntke T. 1997. Early succession of butterfly and plant communities on set-aside fields. Oecologia 109: 294-302.

Steffan-Dewenter I. and Tschantke T. 2000. Butterfly community structure in fragmented habitats. Ecol. Lett. 3: 449-456.

Ter Braak C.J.F. and Smilauer P. 2002. Canoco Reference Manual and CanoDraw for Windows User's Guide. Software for Canonical Community Ordination (version 4.5). Biometris, Wageningen and Cescé Budejovice.

Thomas C.F.G., Parkinson L., Griffiths A., Fernandez Garcia A. and Marshall E.J.P. 2001. Aggregation and temporal stability of carabid beetle distributions in field and hedgerow habitats. J. Appl. Ecol. 38: 100-116.

Tscharntke T. and Greiler H.J. 1995. Insect communities, grasses and grasslands. Ann. Rev. Entomol. 40: 535-558.

Tscharntke T. and Kruess A. 1999. Habitat fragmentation and biological control. In: Hawkins B.A. and Cornell H.V. (eds), Theoretical Approaches to Biological Control. Cambridge University Press, Cambridge, pp. 190-205.

Ullrich K.S. 2001. The influence of wildflower-strips on plant and insect (Heteroptera) diversity in an arable landscape. Ph.D. thesis, ETH, Zürich.

Ullrich K.S. and Edwards P.J. 1999. The colonization of wildflower-strips by insects (Heteroptera). In: Maudsley M.J. and Marshall E.J.P. (eds), Heterogeneity in Landscape Ecology. Proceedings of International Association for Landscape Ecology, UK, pp. 131-138.

Voigt W., Perner J., Davis A.J., Eggers T., Schumacher J., Bährmann R., Fabian B., Heinrich W., Köhler G., Lichter D., Marstaller R. and Sander F. 2003. Trophic levels are differentially sensitive to climate. Ecology 84: 2444-2453.

Wagner E. 1952. Blindwanzen oder Miriden. Fischer, Jena.

Wagner E. 1966. I. Pentatomorpha. Fischer, Jena.

Wagner E. 1967. II. Cimicomorpha. Fischer, Jena. 
Wagner E. 1970-1975. Die Miridae des Mittelmeerraumes und der Makronischen Inseln (Hemiptera, Heteroptera) Teil 1-3. Entomologische Abhandlungen 37. Akademische Verlagsgesellschaft Geest \& Portig, Leipzig.

White P.C.L. and Hassal M. 1994. Effects of management on spider communities of headlands in cereal fields. Pedobiologia 38: 169-184.

Zar J.H. 1996. Biostatistical Analysis. Prentice-Hall International, London. 